\title{
Relationship between Platelet Counts, Mean Platelet Volume, Platecrit and Beta Thalassemia Carriers
}

\section{Beta Talasemi Taşıyıcılarında Platekrit, Ortalama Trombosit Volümü ve Trombosit Sayısı Arasındaki llişki}

\author{
DHatice Tuba Akbayram1', @Mustafa Örkmez² \\ 'Department of Family Medicine, Gaziantep University Faculty of Medicine, Gaziantep, Turkiye \\ ${ }^{2}$ Department of Biochemistiry, Gaziantep University Faculty of Medicine, Gaziantep, Turkiye
}

\begin{abstract}
Aim: $\beta$-thalassemia carriers (BTC) is generally asymptomatic; however, in clinical practice, there is hypochromic microcytic mild anemia caused by a hereditary reduction in beta globin synthesis. In the literature, there is also some information about platelet indices in BTC. The aim of this study was to evaluate platelet indices in children with BTC. In addition, we compared platelet indices between anemia $(\mathrm{Hb}<11 \mathrm{~g} / \mathrm{dl})$ and non-anemia BTC $(\mathrm{Hb} \geq 11 \mathrm{~g} / \mathrm{dl})$.

Material and Method: A cross sectional study included a total of 153 subjects aged 1-16 years were recruited from Gaziantep University Hospital outpatient clinics electronic database.

Results: Platelet counts were normal in 90 patients with BTC. Thrombocytosis and thrombocytopenia were detected in 59 (38.5\%) and four (2.6\%) patients, respectively. This study group was divided into two groups as group 1 , cases $<11 \mathrm{~g} / \mathrm{dl}(\mathrm{n}=86)$, and group 2 , cases $\geq 11 \mathrm{~g} / \mathrm{dl}$ ( $n=67)$ according to the hemoglobin levels. The children with the group 1 had significantly higher mean levels of platelet counts and platecrit than those with group $2(p<0.05)$. In the logistic regression test, linear correlation between platelet counts and platecrit $(r=0.94, p<0.01)$ was observed, whereas there were inverse correlations between platelet counts and age ( $r=-$ $0.32, p<0.01)$, mean platelet volume $(r=-0.18, p<0.05)$, hemoglobin $(r=-0.18, p<0.05)$.

Conclusion: We found that both thrombocytosis and thrombocytopenia may occur in BTC. Herein we also found significantly elevated platelet counts in BTC with anemia.
\end{abstract}

Keywords: Thalassemia, carriers, child, platelet indices
Öz

Giriş: $\beta$-talasemi taşıyıcılığı genellikle asemptomatiktir, bununla beraber beta globin zincirinde kalıtsal azalmadan dolayı hafif hipokromik mikrositer anemi gelişebilmektedir. Literatürde, talasemi taşıyıcılarında trombosit parametrelerini değerlendiren az sayıda çalışma bulunmaktadır. Bu çalışmada amacımız talasemi taşıyıcılarında trombosit parametrelerini değerlendirmektir. Ayrıca çalışmamızda anemili ve anemisiz talasemi taşıyıcılarında platelet parametrelerini değerlendirdik.

Gereç ve Yöntem: Kesitsel çalışmamızda Gaziantep Üniversitesi Tıp Fakültesi ayaktan hasta polikliniklerine başvuran 1-16 yaş arası 153 talasemi taşıyıcısı çocuk çalışmaya alındı.

Bulgular: Doksan çocuğun trombosit sayıları normaldi. 59 (\%38.5) çocukta trombositoz, dört (\%2.6) çocukta trombositopeni saptandı. Hemoglobin seviyelerine göre iki gruba ayrıldı. Grup 1, hemoglobin $<11$ $\mathrm{g} / \mathrm{dl}(\mathrm{n}=86)$, ve grup 2, hemoglobin $\geq 11 \mathrm{~g} / \mathrm{dl}(\mathrm{n}=67)$ 'den oluşmaktaydı. Grup 1 olgularda trombosit sayısı ve platekrit, grup 2 olgularından anlamlı olarak yüksekti. $(p<0.05)$ Logistik regresyon testinde trombosit sayısı ve platekrit arasında lineer bir korelasyon görüldü ( $r=0.94$, $p<0.01)$, ancak trombosit sayısı ile yaş $(r=-0.32, p<0.01)$, ortalama trombosit volumü $(r=-0.18, p<0.05)$, hemoglobin $(r=-0.18, p<0.05)$ arasında negatif bir korelasyon görüldü.

Sonuç: Talasemi taşıyıcılarında hem trombositoz hemde trombositopeni olabileceğini bulduk. Ayrıca anemi gelişen talasemi taşıyıcılarında trombosit sayısı anlamlı olarak yüksekti.

Anahtar Kelimeler: Talasemi, taşıyıcılık, çocuk, trombosit parametreleri

Corresponding (iletişim): Hatice Tuba Akbayram, Gaziantep University, Faculty of Medicine, Department of Family Medicine, 27600 Gaziantep Turkiye

E-mail (E-posta): tubaakbayram@gmail.com

Received (Geliş Tarihi): 22.06.2020 Accepted (Kabul Tarihi): gg.aa.yyyy 


\section{INTRODUCTION}

Anemia is one of the most common public health problems in the world. It is classified in to microcytic, normocytic and macrocytic anemia based on mean corpuscular volume (MCV) of red blood cells (RBC). Microcytic anemia, which is characterized by low MCV is the most common subtype of anemia among children. ${ }^{[1]}$ Although microcytic anemia in children has numerous of etiologies, iron deficiency (ID) is the most well recognized cause across the world. The next most common cause of microcytic anemia is thalassemia carriers. [2] Two major forms of thalassemia are described; $a-$ and $\beta$-thalassemia carriers (BTC). Turkey, which is located in the Mediterranean area, has a very high incidence of BTC, with the country's incidence of BTC at $2.3 \%{ }^{[3]}$

BTC is generally asymptomatic; however, in clinical practice, there is hypochromic microcytic mild anemia caused by a hereditary reduction in beta globin synthesis and the peripheral smear resembles iron deficiency anemia (IDA), these two disorders must be distinguished from each other. ${ }^{[4]}$ BTC is usually diagnosed by measuring concentration of $\mathrm{HbA2}$, and complete blood count. ${ }^{[5]}$ The classical phenotype of BTC includes an increased $\mathrm{HbA} 2$ level (>3.5\%), a relatively high $\mathrm{RBC}$, a markedly reduced $\mathrm{MCV}$ and reduced mean corpuscular hemoglobin levels. ${ }^{[6]}$

IDA is characterized by a defect in hemoglobin synthesis that results in microcytic RBC and decreased amount of hemoglobin $(\mathrm{Hb})$. In addition to anemia, abnormal platelet counts also have been reported in both adults and children with IDA. IDA may cause reactive thrombocytosis and it is mostly mild to moderate. However, thrombocytopenia has also been reported in some patients with IDA. ${ }^{[7-9]}$ Several studies reported an inverse relationship between mean platelet volume (MPV) and platelet counts in patients with BTC. ${ }^{[10-12]}$ This may be related to morphological features of platelets. In the literature, there are also some informations about platelet indices in BTC. ${ }^{[4,13]}$ The aim of this study was to evaluate platelet indices in children with BTC. In addition, we compared platelet indices between BTC with anemia $(\mathrm{Hb}<11$ $\mathrm{g} / \mathrm{dl})$ and without anemia $(\mathrm{Hb} \geq 11 \mathrm{~g} / \mathrm{dl})$.

\section{MATERIAL AND METHOD}

The data gathered from Gaziantep University Hospital outpatient clinics electronic database. The period of this crosssectional retrospective study was from 2019 to 2020 . One hundred and fifty three children were evaluated: 70 females (45.7\%) and 83 (54.3\%) males. Age of the patients was from 1 to 16 years old. The inclusion criteria were child patients more than $3.5 \% \mathrm{HbA} 2$ levels. The hematological parameters were measured using a Sysmex XN1000 analyzer. Serum HbA2 level was done by Interlab Automatic Agarose Gel Electrophoresis System.The study protocol was approved by the Medical Ethics Committee of Gaziantep University.
World Health Organization differentiated cut-off criteria for $\mathrm{Hb}$ by age, sex, and physiological status, it established a single and universal cut-off point of less than $11 \mathrm{~g} / \mathrm{dl}$ when using $\mathrm{Hb}$ for women, infant and children. ${ }^{[14]}$ Diagnosis was performed in all patients quantitative identification of $\mathrm{HbA} 2(>3.5 \%)$ for BTC by gel electrophoresis system. Thrombocytopenia was defined as thrombocyte counts less than $150.000 \mathrm{~mm} 3 / \mathrm{dl}$, however thrombocytosis was defined as thrombocyte counts more than $400.000 \mathrm{~mm} 3 / \mathrm{dl}$ for children in our study. ${ }^{[15]}$ Their platelet indices, thrombocyte count, MPV and platecrit were noted. To calculate the platecrit, the formula, platelet count x MPV/103, was used (e.g. a platelet count of $200 \times 109 /$ and MPV of $9 \mathrm{fl}$ yields a platelet mass of $1800 \mathrm{fl} / \mathrm{hl}$ )

\section{Statistical analysis}

Data were analyzed using SPSS 23.0 software (SPSS, Inc.,Chicago, IL, USA). Demographic data were shown as means and SD or percentages. Categorical variables were compared by using chi-square test. Spearman's correlation analysis was performed to examine the correlations between $\mathrm{HbA} 2$ and age, platelet indices and hematological measures. Two-tailed significance values are reported throughout. A probability level of $p<.05$ was used to indicate statistical significance.

\section{RESULTS}

The sample consisted of 153 children with BTC (83 males, 70 females) with the ages of 1 to 16 (mean $\pm S D=7.1 \pm 4.3$ ) years. The male-female ratio was 1.1. Platelet counts were normal in 90 patients with BTC. Thrombocytosis and thrombocytopenia were detected in 59 (38.5\%) and four (2.6\%) patients, respectively. This study group was divided into two groups as group 1, cases $<11 \mathrm{~g} / \mathrm{dl}(\mathrm{n}=86)$, and group 2 , cases $\geq 11 \mathrm{~g} / \mathrm{dl}$ $(n=67)$ according to hemoglobin levels, and Table 1 shows demographic characteristics of the subjects. The mean \pm SD of laboratory measures, including $\mathrm{HbA} 2$ levels, and platelet indices are summarized in Table $\mathbf{2}$.

\begin{tabular}{|c|c|c|c|}
\hline & Total $n=153$ & $\begin{array}{c}\text { group } 1 \text {, } \\
\text { hemoglobin levels } \\
<11 \mathrm{~g} / \mathrm{dl}(\mathrm{n}=86)\end{array}$ & $\begin{array}{c}\text { group } 2, \\
\text { hemoglobin levels } \\
\geq 11 \mathrm{~g} / \mathrm{dl}(\mathrm{n}=67)\end{array}$ \\
\hline $\begin{array}{l}\text { Age, years } \\
\text { Mean } \pm S D\end{array}$ & $7.1 \pm 4,3$ & $8 \pm 4$ & $9 \pm 4$ \\
\hline \multicolumn{4}{|l|}{ Gender, n (\%) } \\
\hline Male & $83(45.2 \%)$ & $45(52.3 \%)$ & 38 (56.7\%) \\
\hline Female & $70(54.8 \%)$ & $41(43.3 \%)$ & $29(43.3 \%)$ \\
\hline
\end{tabular}

The children with the group 1 had significantly higher mean levels of platelet counts and platecrit than those with group $2(p<0.05)$. On the other hand, the children with group 1 had lower mean levels of $\mathrm{HbA} 2$ and MPV than those with group 2 , however there were no statistical differences in $\mathrm{HbA} 2$ and MPV ( $>0.05$ ). (Table 2) On the other hand, there were no statistical significant difference between males and females in all measures. 


\begin{tabular}{|c|c|c|c|c|}
\hline & Total $n=153$ & $\underset{(n=86)}{\text { group } 1 \text {, hemoglobin levels }<11 \mathrm{~g} / \mathrm{dl}}$ & $\begin{array}{l}\text { group } 2, \text { hemoglobin levels } \geq 11 \mathrm{~g} / \mathrm{dl} \\
(n=67)\end{array}$ & p Value \\
\hline $\mathrm{HbA} 2(\%)$ & $5.1 \pm 3.2$ & $5 \pm 0.8$ & $4.8 \pm 1$ & $p>0.05$ \\
\hline Hemoglobin (g/dl) & $10.8 \pm 1.4$ & $9.9 \pm 0.9$ & $12.1 \pm 0.9$ & $\mathrm{p}<0.0001$ \\
\hline Platelet counts $\left(/ \mathrm{mm}^{3}\right)$ & $389.000 \pm 129.000$ & $409.000 \pm 151.000$ & $366.000 \pm 93.000$ & $\mathrm{p}<0.05$ \\
\hline MPV (/fl) & $9.3 \pm 0.7$ & $9.3 \pm 0.7$ & $9.4 \pm 0.7$ & $P>0.05$ \\
\hline Platecrit (fl/nl) & $3632 \pm 1155$ & $3798 \pm 1338$ & $3419 \pm 830$ & $p<0.05$ \\
\hline
\end{tabular}

Table 3. The relationship between platelet counts and other parameters

\begin{tabular}{|c|c|c|c|c|c|}
\hline & Platelet counts $\left(/ \mathrm{mm}^{3}\right)$ & MPV (/fl) & Platecrit (fl/nl) & Hemoglobin (g/dl) & HbA2 (\%) \\
\hline Platelet counts $\left(/ \mathrm{mm}^{3}\right)$ & - & $-0.180^{*}$ & $0.947^{* *}$ & $-0.186^{*}$ & $0.256^{* *}$ \\
\hline MPV (/fl) & $-0.180^{*}$ & - & 0.097 & 0.022 & -0.019 \\
\hline Platecrit (fl/nl) & $0.947^{* *}$ & 0.097 & - & $-0.197^{*}$ & $0.250^{* *}$ \\
\hline Hemoglobin (g/dl) & $0.186^{*}$ & 0.022 & $-0.197^{*}$ & - & -0.122 \\
\hline $\mathrm{HbA} 2(\%)$ & $0.256^{* *}$ & -0.019 & $0.250^{* *}$ & -0.122 & - \\
\hline
\end{tabular}

In the logistic regression test, linear correlations between $\mathrm{HbA} 2$ and platecrit $(r=0.25, \mathrm{p}<0.01)$ and platelet counts $(r=0.25, p<0.01)$ were observed, whereas there were no correlations between $\mathrm{HbA} 2$ levels and, age $(r=0.14, p>0.05)$, MPV $(r=0.01, p>0.05)$, and Hb levels $(r=0.12, p>0.05)$. There were linear correlations between platelet counts and platecrit $(r=0.94, p<0.01)$, also there were inverse correlations between platelet counts and age $(r=0.32, p<0.01), M P V(r=0.18, p<0.05)$, $\mathrm{Hb}(r=0.18, p<0.05)$. There were linear correlations MPV levels between age $(r=0.25, p<0.05)$. There were inverse correlations between platecrit and $\mathrm{Hb}$ levels $(r=0.19, p<0.05)$, age $(r=0.27$, $\mathrm{p}<0.01$ ) (Table 3).

\section{DISCUSSION}

BTC is a hereditary disease that causes a decrease in beta globin synthesis and is frequently asymptomatic. Since it can cause mild microcytic hypochromic anemia it is frequently identified after blood count is performed for other reasons. ${ }^{[16]}$ It is possible to detect carriers using hematologic findings rather than DNA analysis. Considering that BTC does not need treatment, but the diagnosis of a patient with BTC may cause risk of birth of beta thalassemia major child in the pre-marriage genetic counseling. ${ }^{[17]}$ Our evaluation of platelet indices in BTC yielded noteworthy results.

In the present study, we examined clinical records of 153 consecutive child with BTC, and found 59 (38.5\%) who had thrombocytosis at the time of their first evaluation. Thrombocytosis is observed in many disorders and pathologic states. It may be caused by a reactive mechanism or neoplastic over production. The causes of reactive thrombocytosis include infections, inflammatory situations, malignancies, acute bleeding, and IDA. ${ }^{[18]}$ In IDA, alterations of thrombocyte have been reported. It may cause reactive thrombocytosis and thrombocytosis usually occurs in a mild to moderate degree. ${ }^{[8,9]}$ The mechanism of thrombocytosis in IDA is not yet clear. Several studies have reported a relationship between iron and platelet parameters. ${ }^{[8,19]}$ However, Kadikoylu et al. ${ }^{[7]}$ found no correlation between platelet counts and serum ferritin in stepwise logistic regression test and Kuku et al. ${ }^{[20]}$ also found no significant relationships between platelet counts and serum ferritin. In another study, Mettananda et al. ${ }^{[10]}$ suggested that platelet count was lower in BTC $\left(385.000 \pm 126.000 / \mathrm{mm}^{3}\right)$ compared to IDA $\left(406.000 \pm 107.000 / \mathrm{mm}^{3}\right)$ however, was not significantly different between IDA and BTC. They also observed a weak but statistically significant inverse correlation $(r=-0.25$, $p<0.01$ ) between hemoglobin levels and platelet counts among all patients with microcytic anemia. On the other hand, Holbro et al. ${ }^{[21]}$ found that the platelet counts did not show significant association to the cause of anemia. However, correlation analysis revealed that platelet counts had significantly be it weak correlation to the degree of anemia irrespective of the etiology. This is likely due to the thrombopoietic activity of erythropoietin which is secreted in response to anemia. ${ }^{[22]}$ In relation to these studies, we found that the group 1 (with anemia) had significantly higher mean levels of platelet counts than those with group 2 (without anemia) $(p<0.05)$, however, there were inverse correlation between platelet counts and $\mathrm{Hb}$ levels $(r=-0.18, p<0.05)$.

Thrombocytopenia has also been reported in some children and adults with IDA at the time of diagnosis. Iron deficiencyassociated thrombocytopenia generally has been documented as case reports, and there are only a few published series. ${ }^{[23,24]}$ Gross et al. ${ }^{[25]}$ described the platelet counts in 60 iron-deficient infants and children ages 8 to 24 months and reported that $17(28 \%)$ had platelet counts of less than $175 \times 109 / \mathrm{L}$ (range $50-175 \times 109 / \mathrm{L})$. The mean hemoglobin was $4 \mathrm{~g} / \mathrm{dL}$ in the thrombocytopenic group versus $6 \mathrm{~g} / \mathrm{dL}$ in the 43 other patients, suggesting that the development of thrombocytopenia correlates with more severe iron deficiency. Kuku et al. ${ }^{[20]}$ in the study, thrombocytopenia was found in 13 (2.1\%) patients with IDA at diagnosis. The present study, thrombocytopenia was found in $4(2.6 \%)$ patients with BTC. 
In a previous study, it was shown that MPV was significantly correlated with life span of platelets and was related to platelet morphologic change and activation. ${ }^{[26,27]}$ An increase in MPV is also known to be a dependable marker of platelet activation in vivo. ${ }^{[28]}$ Chandra et al. ${ }^{[29]}$ found an interesting point that has to be highlighted in the study is that apart from red cell parameter, platelet parameters including platelet counts, platecrit, and MPV also showed statistical significant difference between IDA and BTC. In another study, Labib et al. ${ }^{[1]]}$ found no significant difference as regard platelet counts but a significant higher MPV was found in BTC subjects compared with controls. On the other hand, Cikrikcioglu et al. ${ }^{[12]}$ found in the study that, the MPV levels were unexpectedly higher in patients in the BTC group than in the control group. In our study, the children with group 1 lower mean levels of MPV than those with group 2, however there were no statistical differences in MPV ( $p>0.05)$, moreover, there were inverse correlations between thrombocyte counts and MPV levels $(r=0.18, p<0.05)$. The higher MPV observed in BTC may be related to the fact that hyperactive bone marrow in BTC may lead to release of immature platelets in circulation leading to higher MPV.

Platecrit is a measurement derived from the platelet count and the mean platelet volume. It is physiologically the most pertinent parameter and is superior to the platelet count to estimate the platelet status. ${ }^{[30]}$ Kuku et al. ${ }^{[20]}$ retrospectively examined the clinical records of a larger number of IDA to assess abnormal platelet counts, they suggested that platelet counts inversely correlated with platecrit. However, Park et al. ${ }^{[18]}$ studied the relationship between iron and platelet parameters in IDA and thrombocytosis and they found that platelet counts showed linear correlation with platecrit $(p<$ 0.001), moreover, in their study, there was no relationship between platelet counts and $\mathrm{Hb}$. In another study, Kadikoylu et al. ${ }^{[7]}$ evaluated the platelet parameters in IDA they found a linear correlation between platecrit and platelet counts. Also, Bessman et al. ${ }^{[4]}$ were confirmed a linear relationship between platelet counts and platecrit $(p<0.001)$ in the logistic regression test. Our study there were positive correlations between platelet counts and platecrit $(r=0.94, p<0.01)$, also there were inverse correlations between platecrit and $\mathrm{Hb}$ levels $(r=0.19, p<0.05)$.

The limitations of the present study were small sample size, and all platelet indices were not analyzed. We do not know about patients whom on iron levels and iron treatment which could affect the level of HBA2 and the platelet indices. Nevertheless, in these patients we assume that quantitative platelet abnormalities were secondary to anemia rather than to other causes. The other limitations were experience of a single center and lack of a control population.

\section{CONCLUSION}

BTC is one of the most common genetic diseases in children in Turkey. This study demonstrates that thrombocytosis is more frequently seen among BTC with anemia than in without anemia also there were linear correlations between platelet counts and, platecrit however there were inverse correlations between age, MPV, Hb levels, moreover there were linear correlations between platecrit and $\mathrm{Hb}$.

\section{ETHICAL DECLARATIONS}

Ethics Committee Approval: The study protocol was approved by the Medical Ethics Committee of Gaziantep University (Permission granted: 2.4.2020, Decision no: 2020/140).

Informed Consent: Because the study was designed retrospectively, no written informed consent form was obtained from patients.

Referee Evaluation Process: Externally peer-reviewed.

Conflict of Interest Statement: The authors have no conflicts of interest to declare.

Financial Disclosure: The authors declared that this study has received no financial support.

Author Contributions: All of the authors declare that they have all participated in the design, execution, and analysis of the paper, and that they have approved the final version.

\section{REFERENCES}

1. Cascio MJ, DeLoughery TG. Anemia: evaluation and diagnostic tests. Med Clin North Am 2017;101(2):263-84.

2. Mettananda S, de Silva DG. Anaemia in children: are we using the correct prevention strategies?. Ceylon Med J 2017;62(2):73-6.

3. Yesilipek A, Ertem M, Cetin M, et al. HLA-matched family hematopoetic stem cell transplantation in children with beta thalassemia major: The experience of the Turkish Pediatric Bone Marrow Transplantation Group. Pediatr Transplant 2012;16(8):846-51.

4. Bessman JD, Gilmer PR, Gardner FH: Use of platelet volume improves detection of platelet disorders. Blood Cells 1985;11:127-35.

5. Weatherall DJ, Clegg JB. Inherited haemoglobin disorders: an increasing global health problem. Bulletin of the World Health Organization. 2001;79(8):704-12.

6. Giambona A, Passarello C, Renda D, et al. The significance of the hemoglobin $A(2)$ value in screening for hemoglobinopathies. Clin Biochem 2009;42(18):1786-96.

7. Kadikoylu G, Yavasoglu I, Bolaman Z, Senturk T. Platelet parameters in women with iron deficiency anemia. J Natl Med Assoc 2006;98:398-402.

8. Dan K. Thrombocytosis in iron deficiency anemia. Intern Med 2005;44:1025-6.

9. Akan H, Guven N, Aydogdu I, Arat M, Beksac M, Dalva K. Thrombopoietic cytokines in patients with iron deficiency anemia with or without thrombocytosis. Acta Haematol 2000;103:152-6.

10. Mettananda S, Paranamana S, Fernando R, et al. Microcytic anemia in children: parallel screening for iron deficiency and thalassemia provides a useful opportunity for thalassemia prevention in low- and middleincome countries. Pediatr Hematol Oncol 2020;37(4):326-36. doi:10.108 0/08880018.2020.1725200

11. Labib HA, Etewa RL, Atia $H$. The hypercoagulable status in common Mediterranean $\beta$-thalassaemia mutations trait. Int J Lab Hematol. 2015 Jun;37(3):326-33.

12. Cikrikcioglu MA, Celik K, Ekinci I, et al. Mean Platelet Volume in Heterozygous Beta Thalassaemia. Acta Haematol 2017;137(2):100-5.

13. Levin J, Bessman JD. The inverse relation between platelet volume and platelet number. Abnormalities in hematologic disease and evidence that platelet size does not correlate with platelet age. J Lab Clin Med 1983;101:295-307. 
14. Centers for Disease Control and Prevention. Recommendations to prevent and control iron deficiency in the United States. Centers for Disease Control and Prevention. MMWR Morb Mortal WklyRepRecomm Rep. 1998;47:1-29.

15. Subramaniam N, Mundkur S, Kini P, Bhaskaranand N, Aroor S. Clinicohematological study of thrombocytosis in children. ISRN Hematol 2014;2014:389257.

16. Galanello R, Origa R. Beta-thalassemia. Orphanet J Rare Dis 2010;5:11.

17. Kiss TL, Ali MA, Levine M, Lafferty JD. An algorithm to aid in the investigation of thalassemia trait in multicultural populations. Arch Pathol Lab Med 2000;124(9):1320-3.

18. Park MJ1, Park PW, Seo YH, Kim KH, Park SH, Jeong JH, Ahn JY. The relationship between iron parameters and platelet parameters in women with iron deficiency anemia and thrombocytosis. Platelets 2013;24(5):348-51.

19. Nagai T, Komatsu N, Sakata Y, Miura Y, Ozawa K. Iron deficiency anemia with marked thrombocytosis complicated by central retinal vein occlusion. Intern Med 2005;44:1090-2.

20. Kuku I, Kaya E, Yologlu S, Gokdeniz R, Baydin A. Platelet count in adults with iron deficiency anemia. Platelets 2009;20:401-5.

21. Holbro A, Volken T, Buser A, et al. Iron deficiency and thrombocytosis. VoxSang 2017;112(1):87-92.

22. Beguin Y. Erythropoietin and platelet production. Haematologica. 1999;84(6):541-7.

23. Morris VK, Spraker HL, Howard SC, Ware RE, Reiss UM. Severe thrombocytopenia with iron deficiency anemia. Pediatr Hematol Oncol 2010;27(5):413-9.

24. Perlman MK, Schwab JG, Nachman JB, Rubin CM. Thrombocytopenia in Children with Severe Iron Deficiency. J Pediatr Hematol Oncol 2002;24(5):380-4.

25. Gross S, Keefer V, Newman AJ. The platelets in iron-deficiency anemia. I. The response to oral and parenteral iron. Pediatrics 1964;34:315-22.

26. Jagroop IA, Mikhailidis DP. Mean platelet volume is a useful parameter: A reproducible routine method using a modified Coulter thrombocytometer. Platelets 2001;12:171.

27. Park Y, Schoene N, Harris W. Mean platelet volume as an indicator of platelet activation: Methodological issues. Platelets 2002;13:301-6.

28. Gasparyan AY, Ayvazyan L, Mikhailidis DP,Kitas GD: Meanplateletvolume: a link between thrombosis and inflammation? Curr Pharm Des 2011;17:4758.

29. Chandra H, Shrivastava V, Chandra S, Rawat A, Nautiyal R. Evaluation of Platelet and Red Blood Cell Parameters with Proposal of Modified Score as Discriminating Guide for Iron Deficiency Anemia and $\beta$-Thalassemia Minor. J Clin Diagn Res 2016;10(5):EC31-4.

30. Tvedten $\mathrm{H}$, Lilliehook I, Hillstrom A, Haggstrom J. Plateletcrit is superior to platelet count for assessing platelet status in Cavalier King Charles Spaniels. Vet Clin Pathol 2008;37:266-71. 